\title{
ORIGINAL
}

\section{Antioxidative and Antimicrobial Activities of Extracts from Petals of the Tulip (Tulipa gesneriana L.)}

\author{
Makoto OYAIZU*1, Hirokazu OGIHARA*2, and Uhei NARUSE*3 \\ *1 Musashino Nutrition College (3-12-5, Minami, Ikebukuro, Toshima-ku, Tokyo, T171) \\ $* 2$ College of Bioresource Sciences Nihon University \\ (3-34-1, Shimouma, Setagaya-ku, Tokyo, $\mp 154)$ \\ *3 Kamakura Woman's College (1420, Iwase, Kamakura-shi, Kanagawa-ken, †247)
}

\begin{abstract}
A variety of pigments $(\beta$-carotene, vitamin $\mathrm{E}$, etc $)$ can be found in plants and their physiological roles are quite important.

In this study, the tulip was selected as the focal point of attention. Samples were extracted from the petals with water and ethanol and antioxidative and antimicrobial activity was assessed.

Determination was also made of extract content, color, $\mathrm{pH}, \alpha$-tocopherol content and absorption spectra. The antioxidative activity of the water extracts showed the following order : red petals $>$ white petals $>$ yellow petals $>$ purple petals $>$ pink petals, and in the ethanol extracts : purple petal=yellow petals $>$ white petals $>$ red petals. The water and ethanol extracts were antibiotic to essentially the same extent.
\end{abstract}

Key words : tulip, antioxidative activity, antimicrobial activity

\section{Introduction}

The antioxidative and antimicrobial activity of substances extracted from several plants ${ }^{1), 2)}$ was preciously reported. Plants contain many vitamins and pigments and may possibly function to prevent lipid peroxidation and inhibit the formation of lipid peroxides ${ }^{3) \sim 5)}$.

In this study, examination was made of the flowers of various plants and the tulip was selected as the focal point of attention and the antioxidative and antimicrobial activity of substances extracted from tulip petals was determined.

\section{Experimental}

\section{2•1 Sample}

Petals of tulip (Tulipa gesneriana L.) cultivated in Tonami City, Toyama in Japan from late April to the middle of May, 1992 were used. Their colors were red, purple, pink, yellow and white.

\subsection{Materials (crude extract preparation)}

The extraction was conducted using water and ethyl alcohol (ethanol). The water extracts were prepared by adding distilled water to minced tulip petals, followed by grinding filtrating and freeze drying with a vacuum lyophilizer so that the crude extract would be in powder form. To obtain ethanol extracts, ethanol was added to minced petals, and after standing overnight in a cool dark place, the filtrate was vacuum concentrated to give the crude extract in paste form.

\subsection{Crude extract analysis}

Crude extract color, content, $\mathrm{pH}, \alpha$-tocopherol content and absorption spectra were determined $^{4)} \cdot \alpha$-Tocopherol content was measured by high performance liquid chromatography 
(HPLC). The absorption spectra was measured at $380 \sim 800 \mathrm{~nm}$ with a Spectrophotometer (Hitachi).

\subsection{Measurement of antioxidative activity}

The degree of antioxidation of the crude extract was estimated based on oxygen absorption ( $\mathrm{Lu}$ ) by using the Warburg manometric method ${ }^{4)}$.

\subsection{Measurement of antimicrobial activity}

Antimicrobial activity of the crude extract was assessed by the disk method, by which inhibition rings ${ }^{5)}$ can be measured. The sensitivity of Staphylococcus aureus was measured as a gram-positive bacteria, and that of Escherichia coli, as a gram-negative bacteria.

All crude extracts were prepared as 0.5 wt\% solutions and the disks were moistened during preparation.

The diameter of the circle of inhibition was measured and antimicrobial activity was rated as ; $(-)$ : negative $(0 \mathrm{~mm}),(+)$ : positive $(1 \sim 3 \mathrm{~mm}),(++):$ moderately positive $(4 \sim 6 \mathrm{~mm})$, $(+++)$ : strongly positive $(7 \sim 10 \mathrm{~mm})$.

\section{Results and Discussion}

The properties of the crude extracts such as color, content, $\mathrm{pH}, \alpha$-tocopherol content, absorption spectra are shown in Table 1.

The weight of the crude water extract was $1.12-0.65 \%$ and $2.55 \%$ to $1.21 \%$ for the ethanol extract. The $\mathrm{pH}$ of all ethanol extracts was less the that of any water extract, and acidic in all cases. $\alpha$-Tocopherol content of the ethanol extract was 1.31 to $0.50 \mathrm{mg} / 100 \mathrm{~g}$.

Absorption spectra of the water extracts peaked at $597 \mathrm{~nm}$, and the ethanol extracts peaked at different wavelengths.

Crude extract colors were pale yellow, violet and red, thus suggesting the presence of flavonoid pigments in the yellow extracts ${ }^{6)}$ and polyphenol pigments, including anthocyanin ${ }^{7), 8)}$, in the yellow and violet extracts. The crude extracts appeared to contain a wide range of substances hydrophobic or hydrophilic, and thus may have been mixtures poornessing many different pigments.

Crude extracts antioxidative activity data are shown in Table 2.

The order of this parameter for water extracts was as follows : red petals $>$ white petals $>$ yellow petals $>$ purple petals $>$ pink petals, while for ethanol extracts, : purple petals=yellow petals $>$ white petals $>$ red petals. These orders appeared due to carotenoids, flavonoids, or phenols and $\alpha$-tocopherol possessing $\mathrm{OH}$, based on measurement data. From the present study, antioxidative activity would appear due to low-molecular substances, principally polyphenol compounds ${ }^{9}$, that function in a complex manner, and substances with antioxida-

Table 1 Chemical Analysis of Extracts from Petals of Tulip.

\begin{tabular}{l|l|l|c|c|c|c}
\hline \multicolumn{1}{c|}{ Tulip } & Solvent & Extracts color & $\begin{array}{c}\text { Extracts } \\
\text { content (\%) }\end{array}$ & $\mathrm{pH}$ & $\begin{array}{c}\alpha \text {-Tocopherol } \\
(\mathrm{mg} / 100 \mathrm{~g})\end{array}$ & $\begin{array}{c}\text { Absorption wave } \\
(380 \sim 800 \mathrm{~nm})\end{array}$ \\
\hline Red & Water & Violet & 1.00 & 5.60 & - & 597,513 \\
& Ethanol & Red & 2.55 & 4.65 & 1.31 & 587,568 \\
Purple & Water & Red & 1.12 & 6.00 & - & 597 \\
& Ethanol & Reddish-violet & 2.25 & 4.85 & 0.60 & 546,597 \\
Pink & Water & Pale pink & 0.96 & 5.00 & - & 597 \\
& Ethanol & Pale pink & 1.75 & 4.60 & 0.80 & 532 \\
Yellow & Water & Pale yellow & 0.65 & 5.20 & - & $597,485,453$ \\
& Ethanol & Yellow & 1.21 & 4.80 & 0.50 & $597,460,435$ \\
White & Water & Pale pink & 1.00 & 5.60 & - & 597 \\
& Ethanol & Pale pink & 2.55 & 4.80 & 0.70 & 597 \\
\hline
\end{tabular}


Table 2 Antioxidative Activity of Extract from Petals of Tulip.

\begin{tabular}{l|c|c}
\hline \multirow{2}{*}{ Tulip } & \multicolumn{2}{|c}{ Antioxidative activity (\%)*1 } \\
\cline { 2 - 3 } & Water extract*2 & Ethanol extract*2 \\
\hline Red & 14.2 & 25.0 \\
Perple & 5.0 & 31.8 \\
Pink & 1.5 & 2.3 \\
Yellow & 10.0 & 31.8 \\
White & 12.5 & 27.2 \\
\hline
\end{tabular}

*1 Antioxidative activity value were measument at $60 \mathrm{~min}$. $\frac{\text { Blank [oxygen uptake }(\mathrm{uL})]- \text { Sample [oxygen uptake }(\mathrm{uL})]}{\text { Blank }} \times 100$ Blank [oxygen uptake (uL)]

*2 Added 10\% extract material

Table 3 Antimicrobial Activity of Extract from Petals of Tulip.

\begin{tabular}{l|c|c|c|c}
\hline \multirow{2}{*}{ Tulip. } & \multicolumn{2}{|c|}{ Water extract } & \multicolumn{2}{c}{ Ethanol extract } \\
\cline { 2 - 5 } & \multicolumn{4}{|c}{ Strains } \\
\cline { 2 - 5 } & E. coli & S. aureus & E. coli & S. aureus \\
\hline Red & $++* 1$ & ++ & ++ & ++ \\
Purple & ++ & ++ & ++ & ++ \\
Pink & ++ & + & ++ & + \\
Yellow & ++ & ++ & ++ & ++ \\
White & +++ & +++ & +++ & +++ \\
\hline
\end{tabular}

$* 1 \quad(-)$ : negative $(0 \mathrm{~mm}),(+)$ : positive $(1 \sim 3 \mathrm{~mm}),(++)$ : moderately positive $(4 \sim 6 \mathrm{~mm}),(+++)$ : strongly positive $(7 \sim 10 \mathrm{~mm})$

tive activity in the water extracts may contain vitamin $\mathrm{C}^{10)}$ and tannins.

Antimicrobial activity data for the crude extracts are presented in Table 3.

Petals are reproductive tissues and may contain the greatest amount of the antibiotic substances ${ }^{11)}$ and this may explain crude extracts in the present study expressed antimicrobial activity toward gram-negative, gram-positive bacteria. The effects of substances from white petals, especially those extracted with water and ethanol, may possibly be due to pigments which possessing phenolic polyphenol, low-molecular, and polyphenol compounds.

\section{Conclusion}

Antioxidant and antibiotic properties of substances extracted with water and ethyl alcohol from red, purple, pink, yellow and white tulip petals were examined and the following results were obtained.

1) The antioxidative activity of the water extracts showed the following order : red petals $>$ white petals $>$ yellow petals $>$ purple petals $>$ pink petals, and in the ethanol extracts : purple petals $=$ yellow petals $>$ white petals $>$ red petals.

2) All of the water and ethanol extracts had essentially the same antibiotic activity.

(Received : Jan. 31, 1996 ; Accepted : Sept. 7, 1996) 


\section{References}

1) S. Toda, H. Tanizawa, H. Arichi, Y. Takino, Yakugaku Zasshi, 104, 394 (1984).

2) J.D. Su, T. Osawa, M. Namiki, Agric. Biol. Chem., 50, 189 (1984).

3) T. Miyamoto, J. Antibact. Antifung. Agents, 14, 517 (1986).

4) M. Oyaizu, H. Ogihara, U. Naruse, J. Jpn. Oil Chem. Soc., 40, 511 (1991).

5) M. Oyaizu, H. Ogihara, K. Sekimoto, U. Naruse, J. Jpn. Oil Chem. Soc., 42, 1003 (1993).

6) N. Nakatani, H. Kikuzaki, Nippon Nogeikagaku Kaishi, 69, 1189 (1995).

7) Y. Endo, R. Usuki, T. Kaneda, J. Am. Oil Chem. Soc., 62, 1375 (1985).

8) Y. Endo, R. Usuki, T. Kaneda, J. Am. Oil Chem. Soc., 62, 1387 (1985).

9) J.M. Schulz, K. Herrmann, Z. Lebensm. Unters. Forsch., 171, 193 (1980).

10) K. Takamiya, M. Abe, I. Otsuka, A. Okawara, A. Ono, J. Cookery, Sci., Japan, 20, 32 (1991).

11) M. Tada, K. Okuno, K. Chiba, E. Ohnishi, T. Yoshii, Phytochemistry, 35, 539 (1994). 


\title{
日本油化学会誌本号掲載 論文要旨
}

\begin{tabular}{|c|c|}
\hline [総説 $]$ & $\begin{array}{c}\text { 高度不飽和油脂の自動酸化に対する } \\
\text { 含公素リン脂質の酸化防止効果 }\end{array}$ \\
\hline & $\begin{array}{c}\text { 戸 谷 洋一郎 } \\
\text { 成蹊大学工学部 ( } \text { (180 東京都武蔵野市吉祥寺北町 3-3-1) }\end{array}$ \\
\hline $\begin{array}{l}\text { 非水系 } \\
\text { ジルエタ, } \\
\text { チルエタ } \\
\text { (PS), エま } \\
\text { 価した。 } \\
\text { 試験した } \\
\text { ながら, } \\
\text { 察された。 } \\
\text { えられた。 }\end{array}$ & 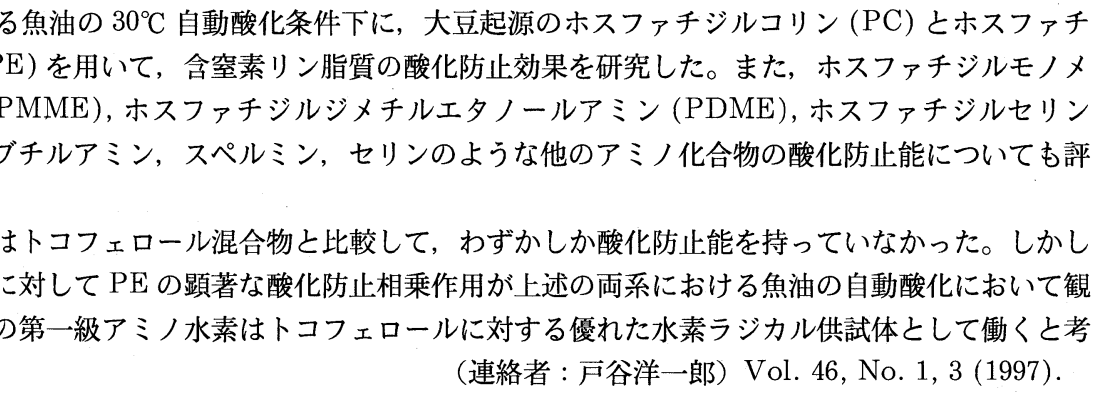 \\
\hline
\end{tabular}

\section{[報文］チューリップ (Tulipa gesneriana L.)}

\section{花弁抽出物質の酸化防止性及び抗菌性について}

\author{
小 柳 津 周*1 • 荻 原 博 和 ${ }^{* 2}$ 成 瀬 宇 平*3 \\ *1 武咸野栄養専門学校 (下171 果京都豊島区南池袋 3-12-5) \\ $* 2$ 日本大学生物資源科学部 ( 1154 東京都世田谷区下馬 3-34-1) \\ *3 鎌倉女子大学 (干247 神奈川県鎌倉市岩瀬 1420)
}

植物には，色素やビタミン剤（ $\beta$-カロテンやビタミン E など）が多様に存在し，それらが生理活性作用に深く 関与していることが知られるようになった。

本研究では, チューリップを選択した。試料はチューリップ花弁から水とエタノールで抽出した，そして酸化防 止性と抗菌性を評価した。抽出物質は, 含有量, 色調, $\mathrm{pH}, \alpha$-トコフェロール量及び吸収スペクトルをそれぞれ 測定した。酸化防止性は, 水抽出物質で赤色花弁 >白色花弁 > 黄色花弁 > 紫色花弁 > 桃色花弁, エ夕ノール抽出物 質では紫色花弁 $=$ 黄色花弁 $>$ 白色花弁 $>$ 赤色花弁 $>$ 桃色花弁の順であった。さらに，抗菌性は水及びエタノール抽 出物質ともに同様の効果を示した。

(連絡者：小柳津周）Vol. 46, No. 1, 17 (1997).

\section{[報文］＼cjkstart乳化系におけるリン脂質の酸化防止効果}

\author{
渡邊 将 人・原節子・戸 谷 洋一郎 \\ 成蹊大学工学部 (T180 東京都武蔵野市吉祥寺北町 3-3-1)
}

大豆リン脂質から調製したホスファチジルコリン $(\mathrm{PC})$, ホスファチジルエタノールアミン $(\mathrm{PE})$ 及び $\mathrm{PC}$ 濃縮 リン脂質 (PC-70) の酸化防止作用とトコフェロールに対する酸化防止相乗効果について, $30^{\circ} \mathrm{C}$ の自動酸化条件下 に精製魚油/水 $(3 / 7, \mathrm{vol} / \mathrm{vol})$ の乳化系を用いて検討した。 